DOI: $10.30519 /$ ahtr.573163

Advances in Hospitality and Tourism Research (AHTR)

\title{
ENOGASTRONOMY IN NORTHERN PORTUGAL: DESTINATION COOPERATION AND REGIONAL IDENTITY
}

\author{
Susana RACHÃO ${ }^{1}$ \\ Department of Economics, Management, Industrial Engineering and Tourism, University of \\ Aveiro, Portugal \\ ORCID: 0000-0002-9009-0251
}

Zélia BREDA

Department of Economics, Management, Industrial Engineering and Tourism, and Research Unit 'Governance, Competitiveness and Public Policies', University of Aveiro, Portugal ORCID: 0000-0002-5882-063X

\section{Carlos FERNANDES}

School of Technology and Management, Polytechnic of Viana do Castelo, Portugal ORCID: 0000-0002-7656-8765

\section{Veronika JOUKES}

Department of Economics, Sociology and Management, School of Human and Social Sciences, University of Trás-os-Montes and Alto Douro, Portugal

ORCID: 0000-0002-0518-8511

\begin{abstract}
This study aims to understand how conflicting stakeholders' interests and agendas of the public, private and non-profit sectors may affect the management of the tourism destination identity. It focuses on Northern Portugal, a geographical area with contrasting characteristics, ranging from coastal urban areas to rural hinterland, each dealing with different development issues. The study is qualitative in nature, being carried out using indepth interviews conducted with various stakeholders (public, private and non-profit sectors) at three wine regions located in Northern Portugal. Data was examined through content analysis. The findings suggest that there is an evident lack of cooperation between the food-and-wine and the tourism sectors in the three
\end{abstract}

\section{Article History}

Received 31 May 2019

Revised 3 December 2019

Accepted 4 December 2019

\section{Keywords \\ food-and-wine \\ tourism \\ regional identity \\ cooperation \\ local products}

1 Address correspondence to Susana Rachão, PhD Candidate, Department of Economics, Management, Industrial Engineering and Tourism, University of Aveiro, PORTUGAL. Email: susanarachao@ua.pt 
wine regions, which tends to hinder the construction of a territorial identity for development purposes. This study identifies the role of public organisations in promoting a shared vision for endogenous products alongside local stakeholders, thus contributing to the construct of a territorial identity. Although regional identity is studied in the relatively limited context of cooperation among stakeholders' practices, the paper exemplifies how local food and wine products can enhance the identity of tourism destinations.

\section{INTRODUCTION}

Previous studies have acknowledged the importance of local food as an element of cultural identity of place (Mkono, 2011), and that the preservation of traditional food production sustains the regional and national identities of a tourism destination (Kim \& Iwashita, 2016). Akin, the uniqueness and authenticity of local food are important markers in constructing the identity of a destination (Chatzopoulou et al., 2019; Ellis et al., 2018; Everett \& Aitchison, 2008; Stone et al., 2019; Ting et al., 2019). Furthermore, a recent study found that the tourists' emotional bond (place attachment) may impact their return intention to a food destination (Yeap et al., 2019).

As tourists are increasingly engaging in personalised food-andwine experiences at destinations visited (OECD, 2018), more entrepreneurial businesses related to food-and-wine are emerging, for example food vendors attending festivals, street food and other micro food providers (Kline et al., 2014). However, an overweight of micro stakeholders in the food-and-wine sectors may not be in tune with the needs of local economies (Thomas et al., 2011), and by dominating the industry, particularly in peripheral areas, they may function as an obstacle to the improvement of the tourism product (Getz \& Carlsen, 2005).

Tourism has become an important industry in Portugal, both in urban and rural areas, contributing to the economic development of local communities (Turismo de Portugal, 2016), in which the value of food-andwine landscapes are recognised as important dimensions of the country's economy (Silva et al., 2018). Yet, the evolution of food-and-wine tourism was slower compared to other tourism products. In fact, food and wine tourism is a rather recent activity in Portugal. Until 2013, the country had 339 wine tourism units, of which 78\% had initiated their activity after 2000 (Turismo de Portugal, 2014). Portugal's National Tourism Authority 
(Turismo de Portugal, IP) has placed increased emphasis on destination competitiveness based on its food-and-wine heritage, inherent in the Portuguese Tourism Strategy 2027 (Araújo, 2017).

But the Portuguese tourism industry, similar to other European countries, is fragmented and the majority of businesses are micro-sized (Banco de Portugal, 2014; Mykletun \& Gyimo, 2010). This is quite evident when it comes to wine tourism businesses where the average number of full-time workers is five (Turismo de Portugal, 2014), and in the accommodation and restaurant sectors the number drops to an average of three employees (PORDATA, 2019).

According to Lee et al. (2017), the fragmentation of the food-andwine sectors may have negative impacts on the tourism destination identity, a phenomenon that requires more research to be fully understood and managed. Yet, despite the importance of food-and-wine tourism for local economies, little research has been undertaken on the cooperation of various stakeholders in food tourism to sustain a destination identity (Correia et al., 2014; Everett \& Slocum, 2013; McGregor \& Robinson, 2019). As acknowledged by Staggs and Brenner (2019), a coherent collective identity requires a shared perspective amongst stakeholders. Similarly, due to the increasing importance of micro food-and-wine entrepreneurship, it is important to understand how conflicting stakeholders' interests and agendas (of the public, private and non-profit sectors) may affect the management of the tourism destination identity.

Based on this rationale and to achieve the research purpose, two (2) objectives have been defined:

Objective (1) - To analyse the influence of cooperation between the foodand-wine and the tourism sectors on a structured destination identity;

Objective (2) - To understand how local stakeholders perceive the enogastronomic identity of Northern Portugal.

This case study offers theoretical insight into the relationships between food-and-wine and tourism stakeholders and how their cooperation may affect the destination/territorial identity.

The paper begins by outlining concepts on cooperation among tourism industry stakeholders, particularly focusing on food-and-wine tourism contexts. It then briefly discusses relevant existing theories on territorial/regional identity and shifts to the analysis of empirical data obtained from interviews with key stakeholders within the research 
setting. The paper ends with the main conclusions, as well as the limitations of the study and some suggestions for future research.

\section{THEORETICAL BACKGROUND}

\section{Cooperation among tourism industry stakeholders}

There is a significant number of theoretical and empirical research related to cooperation in tourism destinations, particularly about the different levels of cooperation between tourism industry stakeholders (Beritelli, 2011; Boesen et al., 2017; Czernek, 2013; Damayanti et al., 2017; Wang \& Xiang, 2007). However, it is not the purpose of this research to develop a new theory on cooperative matters, but rather to understand how cooperation can be decisive for the success of a strong identity of foodand-wine tourism destinations.

One of the growing tourism trends is the pairing of wine with quality food products, prepared by local chefs and/or the organisation of events and exhibitions which are linked to culinary demonstrations (Telfer, 2001). To provide this type of food-and-wine experiences, the involvement of multiple stakeholders from different sectors is necessary (Getz, 2000). These multiple stakeholders (food providers, wineries, farms, accommodation facilities, tour operators) must share a common vision in order to develop composite tourism products; yet, competing individual interests and conflicts may interfere in its development (Alonso \& Northcote, 2008; Gammack, 2006).

Given the fragmentation of the tourism industry, one fundamental key issue for a successful territorial identity promotion is the cooperation among stakeholders (Damayanti et al., 2017; Ottenbacher \& Harrington, 2013). As mentioned above, food-and-wine-related tourism businesses are characterised by their micro and small scale. Therefore, they tend to trigger entrepreneurial activities (Lee et al., 2017), as small-scale boutique wineries (Dawson et al., 2011), innovative food-related facilities (Hjalager \& Johansen, 2013) and third-wave coffee shops (Lee et al., 2017), just to name a few examples. For that reason, cooperation among small food-andwine businesses might benefit the structural development of a territorial identity.

Zhang et al. (2009) point out that cooperation is a form of an interfirm relationship in a tourism supply chain. For Correia et al. (2014, p. 45), cooperation describes "the intentional and voluntary 
relationships/initiatives in which two or more independent businesses and/or individuals interact". Cooperation among stakeholders can take a form of micro-clusters, allowing innovation through interaction and facilitating knowledge sharing (Braun \& Hollick, 2006). At the same time, tourists benefit from these micro-clusters as they reduce search and travel costs, and raise the associated tourism experience (Taylor et al., 2007).

Cooperation might be shaped by specific social contexts of countries/regions as business life cycles, demographic features and spatial determinants (Czernek, 2013). Based on research in Australia, it was suggested that wine tourism industry members are more keen to participate in cooperative activities (Taylor et al., 2007). Correia et al. (2014), studying cooperation among wine and tourism businesses in the Douro Valley, confirmed this finding for the Portuguese context.

If destination stakeholders fail in defining the regions' attributes or landmarks (Silva et al., 2018), the regional identity may become confusing in the eyes of the visitors. For that reason, branding a food-and-wine destination requires a considerable negotiation among key stakeholders to define the place's identity which should emphasise the uniqueness of local food (Lai et al., 2019).

\section{Territorial and regional identities}

The development of territorial valorisation strategies is seen as a consequence of a postmodern society strongly marked by the standardisation of products and services (Rachão et al., 2019). The Protected Designation of Origin (PDO) and the Protected Geographical Indication (PGI) labels, for example, illustrate how the European Agrarian Policies operationalises the preservation and strengthening of endogenous food-and-wines (Silva et al., 2018).

As a form of differentiation, in a globalised crowded marketplace, many destinations have been using food as a form of attraction (Frochot, 2003; Lin et al., 2011). This is because the uniqueness of local food and wine products (Haven-Tang \& Jones, 2008), deeply rooted into a place (Frochot, 2003; Lin et al., 2011), can reinforce cultural differences among regions and countries (Fox, 2007). By using such endogenous products, destinations have the opportunity to increase the uniqueness of their identity, and, additionally, to formulate a unique selling proposition (Haven-Tang \& Jones, 2008). The increasing interest in cooking, dining 
locally, and travelling for and socialising through food experiences (Kline et al, 2014) has led to the growth of tourists seeking novelty in experiences focused on local food heritage (Presenza \& Chiappa, 2013).

Additionally, food-and-wine production methods are connected to gastronomic traditions which have a great role in marking the regional identity of places (Corigliano, 2015; Hashimoto \& Telfer, 2006). These production methods (wine, dairy products, olive oil, among others) can also support the development of unique food-and-wine experiences that policymakers may link with local communities as they are a part of a destination's identity (Lin et al., 2011), and thereby of the territory (Corigliano, 2015). The natural landscape of territories is also considered as a unique characteristic (attribute) of a food and wine destination (Scorrano et al., 2018), and the quality of the experience of the viticultural (wine-growing) landscapes or grape-wine environments has a critical impact on the attitude of tourists towards the destination (Quintal et al., 2015). Moreover, shared local identities and visions may facilitate the involvement and commitment of local stakeholders in decision-making processes (Sto \& Vanneste, 2018). As acknowledged by Hallak et al. (2012), entrepreneurial success drifts from the tourism entrepreneur's sense of identity with the place where the business is operating.

This overview of the literature emphasises the need for a better understanding of the issues involved in the development of a territorial identity based on its endogenous resources, such as food-and-wine, as well as the local stakeholders.

\section{Research setting: The Douro, Vinho Verde and Trás-os-Montes wine regions}

Like other food-and-wine destinations, such as France, Italy and Spain, Portugal is now promoting its enogastronomic offer of local cuisine and terroir to attract tourists. The positive influence of gastronomy on international visitors' satisfaction has been confirmed in different regions of Portugal, namely in Porto (Ramires et al., 2018), but also the Algarve (Serra et al., 2015) and the Alentejo (Amaral et al., 2016). To satisfy the ever demanding tourist market, Portugal offers several certified regional/traditional products ranging from dairy products, such as cheese, dry fruits (e.g. almonds and chestnuts), honey, olive oil, to different types of animal meat (beef, pork and lamb) (DGADR, 2019). Portugal has 14 demarcated wine regions (Wines of Portugal, 2016), 14 wine routes, 31 
Denominations of Origin (DO) and 10 Geographical Indications (GIs) (IDTOUR, 2016), and has world primacy regarding the number of indigenous wine grape varieties (Silva et al., 2018). These Portuguese endogenous products associated to food and wine heritage could become even stronger identity markers, as reviewed in the literature. Additionally, Portugal is the 11th world wine producer (IVDP, 2017), with the Douro Valley (in the mainland) - Alto Douro Wine Region - and the Pico Island (Azores Archipelago) - Landscape of the Pico Island Vineyard Culture are recognised as world heritage by the United Nations' Educational, Scientific, and Cultural Organization (UNESCO) (Silva et al., 2018). Also, Portugal has created a brand associated to the traditional and authentic image found in its privately-owned wine tourism estates (Quintas) (Ramos et al., 2018), mostly located in the countryside. To further explore the potential of food and wine tourism, an informal group of producers was established to promote traditional Portuguese gastronomy and stimulate short food supply chains (no more than one intermediary) branded as 'Prove Portugal' (https://tasteportugal.com/). This initiative has encountered mixed results, some positive and some negative. Considerable work needs to be carried out including the increased integration of local producers, whom tend to be declining in number due to rural exodus (Silva et al., 2018).

For this study, the North of Portugal was chosen. With around 3.6 million inhabitants, composed of 86 municipalities and 1,426 parishes, this region accounts for almost $35 \%$ of Portugal's resident population, and about $29 \%$ of the national economy's Gross Domestic Product (GDP) (CCDRN, 2019).

Northern Portugal is a relevant food-and-wine destination because, for example, 21 of the 65 traditional Portuguese products certified as PDO, are from this region (DGADR, 2019). Moreover, the majority of its territory is covered by demarcated wine regions: two major regions, namely Douro and Vinho Verde, and two smaller regions, Trás-os-Montes and TávoraVarosa (Marques \& Marques, 2017). This study will only focus on the first three wine regions (Figure 1).

The Douro Valley is renowned as the place of origin of the Port wine and as the first demarcated and regulated wine region in the world, since 1756 (IVDP, 2017). In 2001, part of this region, the Alto Douro Vinhateiro (Upper Douro Valley) was classified by the UNESCO as a World Heritage Site because of "its cultural, evolutionary and living landscape" (IVV, 2015, p. 118). Concerning the Vinho Verde, it is 
Portugal's largest demarcated region in geographical terms, as well as one of the largest in Europe, extending over 34,000 hectares throughout the northwest of Portugal (CVRVV, 2019). It also hosts the sub-region Vinho Verde Alvarinho. The wine demarcated region of Trás-os-Montes has a "secular origin, being intrinsically marked by winepress basins dug in the rock of Roman and Pre-Roman origin" (ENOTUR, 2016).

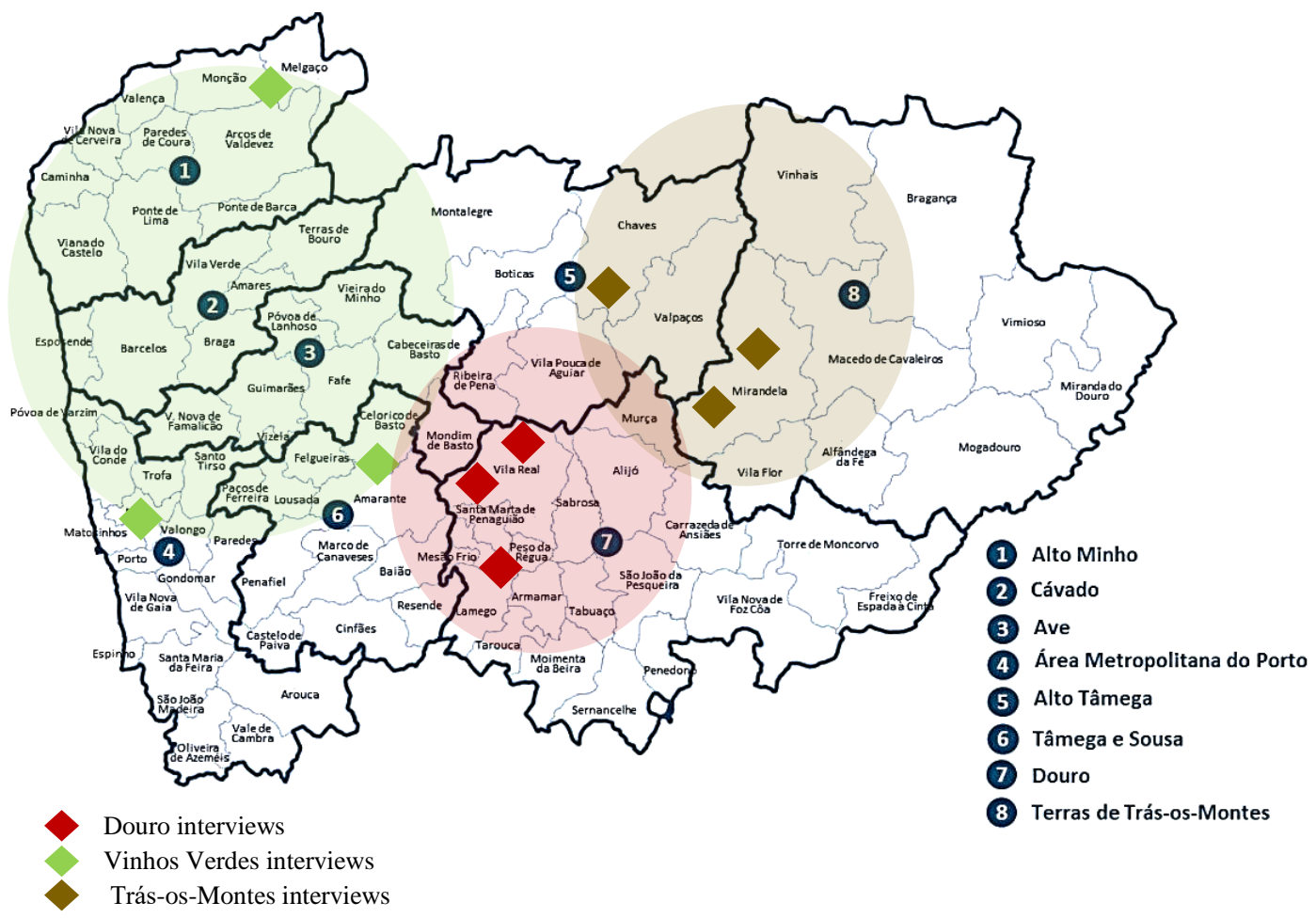

Figure 1. Northern Portugal and the regions in which the interviews took place Source: Northern Portugal Regional Coordination and Development Commission (CCDR-N), 2019

This section described the overall resources for food-and-wine and tourism present in Northern Portugal, relating them as core factors of differentiation and attractiveness of this region. The following section presents the main objectives and research questions and explains the methodological processes to collect and analyse the research data.

\section{METHODOLOGY}

To gain insights into a specific phenomenon, this study follows a phenomenological research philosophy (Altinay \& Paraskevas, 2008) to understand the people's meanings, their own explanations of their behaviour (Clark et al., 2007; Veal, 2006). This exploratory study employed 
in-depth interviews to obtain the opinion of individuals (Creswell, 2009) within their real-life context (Ritchie et al., 2005; Veal, 2006).

Qualitative in-depth interviews were conducted with nine public, private and non-profit key stakeholders, between January and April 2017, in the regions illustrated in Figure 1. The face-to-face interviews took place at the participants' place of business, and each interview took about 60 to 90 minutes. The interviewees were selected based on their significant involvement in food-and-wine and tourism networks in Northern Portugal. Within each wine region, they represent different activity sectors, namely: accommodation, societies, governance, restaurant and wine production (Table 1). Therefore, purposive sampling was employed as it restricts to more experienced individuals (Altinay \& Paraskevas, 2008; Veal, 2006) and provides quality data about a relatively short period of time (Bertella et al., 2018).

Table 1. Interviewees' profile

\begin{tabular}{|c|c|c|c|c|}
\hline Interviewee & $\begin{array}{l}\text { Wine } \\
\text { Region }\end{array}$ & Business operation & Overlap with tourism & Sector \\
\hline TOM1 & \multirow{3}{*}{$\begin{array}{l}\text { Trás-os- } \\
\text { Montes } \\
(\mathrm{TOM})\end{array}$} & Policy maker & $\begin{array}{l}\text { Coordinates events within food } \\
\text { and wine tourism }\end{array}$ & Public \\
\hline TOM2 & & $\begin{array}{l}\text { Head of food and } \\
\text { wine brotherhood }\end{array}$ & No overlapping & $\begin{array}{l}\text { Non- } \\
\text { profit }\end{array}$ \\
\hline TOM3 & & Wine producer & Wine tastings and winery visits & Private \\
\hline D4 & \multirow{3}{*}{ Douro (D) } & Restaurant owner & $\begin{array}{l}\text { Restaurant serves both } \\
\text { tourists/visitors and residents }\end{array}$ & Private \\
\hline D5 & & $\begin{array}{l}\text { Country house } \\
\text { owner }\end{array}$ & $\begin{array}{l}\text { Accommodation and wine } \\
\text { tourism activities }\end{array}$ & Private \\
\hline D6 & & Wine policy maker & No overlapping & Public \\
\hline VV7 & \multirow{3}{*}{$\begin{array}{c}\text { Vinhos } \\
\text { Verdes } \\
(\mathrm{VV})\end{array}$} & Wine policy maker & No overlapping & Public \\
\hline VV8 & & Policy maker & $\begin{array}{l}\text { Coordinates events within food } \\
\text { and wine tourism }\end{array}$ & Public \\
\hline VV9 & & $\begin{array}{l}\text { Accommodation } \\
\text { manager }\end{array}$ & $\begin{array}{l}\text { Hotel accommodation related to } \\
\text { wine }\end{array}$ & Private \\
\hline
\end{tabular}

A four-section framework to guide the in-depth interviews with local stakeholders was employed addressing the following research issues: (1) the closeness/proximity of cooperation among stakeholders of the foodand-wine and tourism sectors; (2) perceptions of competition or conflict between food-and-wine and tourism businesses within the same wine 
region; (3) aspects considered the most relevant for the region's identity; and (4) the role of gastronomy in regional territorial dynamics.

A total of four academics participated in the pre-test to avoid possible ambiguous words and shortcomings. Minor adjustments were made to the wording of questions. Despite the defined interview protocol, supplementary issues emerging from the interview were added. As suggested by Clark et al. (2007), face-to-face interviews can benefit from supplementary questions, direct invitations to go deeper, and from openended questions that allow longer answers.

Participants were informed of the objectives of the study, and the in-depth interviews were audio-recorded, with prior approval. Transcripts of the interviews were then coded and categorized into emerging themes and sub-themes with the assistance of NVivo 11 Pro, a computer-assisted qualitative data analysis software (CAQDAS).

The interview data were submitted to a qualitative thematic analysis (Fox et al., 2010; Neuman, 2014), in which data reduction, proceeded by data display, was applied to draw conclusions. The emerging themes and sub-themes were developed gradually and collaboratively based on the coding process. Additionally, a deductive content analysis was employed as the themes were grounded on the theory developed in the literature review section. Some procedures were implemented during the research data analysis to ensure the validity of the findings. Firstly, a high degree of consensus of the codes (emerging themes) was reached by applying a triangulation of the researchers (Decrop, 1999; Dwyer et al., 2012; Verma \& Chandra, 2018). At least three coders were appointed to secure reliability and provide the most objective insight for each theme assessment. Secondly, emerging themes were subjected to a process of continuous comparison through inter-coder agreement (Creswell, 2009). The first author of this paper coded transcriptions individually and the second author verified the coding in order to have a systematic coding reliability.

The next section presents the results of the qualitative thematic analysis of the interview data and discusses the main research findings.

\section{FINDINGS AND DISCUSSION}

The findings revealed four major themes (1) scarce and informal cooperation, (2) competition and conflict between stakeholders, (3) wine 
region attributes and (4) the role of gastronomy in territorial dynamics. Within the latter key theme, the complementary of gastronomy and wine, the creativity in enogastronomy, the potential of gastronomy in promoting wine, the lack of gastronomic quality and the creation of micro-thematic routes emerged and are discussed to demonstrate how these dimensions may affect the management of the tourism destination identity.

\section{Informal cooperation}

As illustrated in Table 2, the first theme arising from the in-depth interview data, and labelled as "scarce and informal cooperation", demonstrates that the few existing types of cooperation among stakeholders are based on inter-personal relationships and trust. This study thus supports Beritelli's (2011), Damayanti et al.'s (2017), and Wang and Xiang's (2007) notion that friendship ties and trust are a common cooperative inter-firm strategy, in which decisions are made at a personal level.

Stakeholders in the Vinho Verde region recognise that, despite the lack of a structured wine tourism supply, the wineries should collaborate, as they have a wide range of different wines and tourism services. Overall, there is no strong cooperation among wineries, wine museums, and other tourism support services (e.g. accommodation units, entertainment businesses, tour operators). This supports the work conducted by Correia et al. (2014), in which they conclude that food-and-wine and tourism stakeholders in the Northern Portuguese wine regions usually do not cooperate.

Cooperative strategies (particularly, informal partnerships) were developed mainly by medium to large sized businesses. These include partnerships with businesses specialised in outdoor sports activities that provide tourists with things to do in the region. This approach to cooperation supports Telfer's (2001) findings which show that the commitment of the wine industry to tourism is partly related to the age of the winery and the availability of financial resources.

Nonetheless, in a small wine sub-region within the Vinho Verde region (producing the alvarinho variety), the local stakeholders are managed by the two municipal councils, respectively, the level of local cooperation is higher. The key role of public governance lays within managing/supporting stakeholders' involvement in and commitment to a 
successful food-and-wine tourism destination. This governance structure, discussed by Wang and Xiang (2007), who suggested that stakeholders may overcome problems of collaboration and coordination in the market place through a hierarchical/public mode of governance, was reinforced by the participants' responses.

Table 2. Stakeholders' cooperation

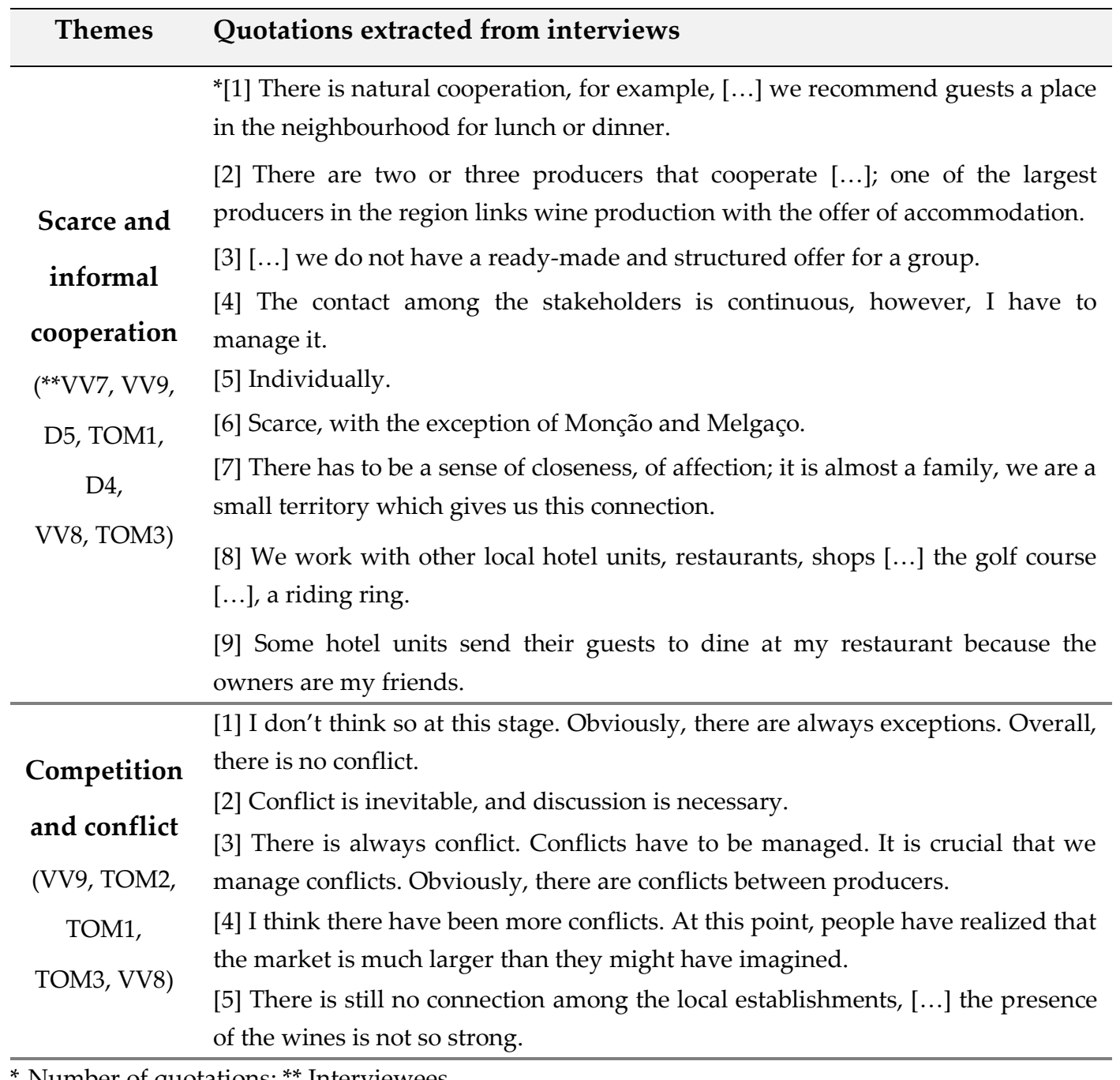

* Number of quotations; ${ }^{* *}$ Interviewees

Nevertheless, there was no consensus amongst the interviewees regarding this public governance mode. This was evident in statements like "Where the government regulates and supports people, it can be a good system, but it must be recognised that [...] people and private businesses have to fight for their own interests" (Interviewee VV7). 


\section{Competition and conflict}

When questioned about potential competition and conflicts, respondents, particularly those in the wine industry, showed different positions on the topic, illustrating different realities between wine regions. The Vinho Verde stakeholders concur that there is still insufficient competition as they are in an initial stage of food-and-wine tourism development: "The wine producers are all very young, as well as are the members of the wineries, but there is a dynamic tendency on the part of the young" (Interviewee VV7). On the other hand, in the Trás-os-Montes region conflicts between stakeholders are very common and they are usually resolved and/or managed by local non-profit organisations and associations, acting as mediators. This was revealed in statements such as "Producers who do not talk to each other sometimes have to share the same spaces in festivals and events; obviously, we cannot place them close to each other" (Interviewee TOM1). Yet, some local businesses are starting to cooperate as they recognise the need to offer a more integrated foodand-wine tourism supply. "They also realised that with an isolated, selfish strategy, they will not succeed" (Interviewee TOM3).

\section{Wine region attributes}

Interviewees acknowledged that the gastronomic heritage is an important attribute of the territorial identity, as illustrated in Table 3. The agricultural products such as almonds, olives, mushrooms, the animal production (lamb), and their use in traditional food recipes were emphasised. This supports the work of Haven-Tang and Jones (2008), who recognise local food and wines as identity marks of a destination, and a source of identity formation in post-modern societies (Richards, 2002). In this context, food tourism can be an important means of strengthening a region's identity (Everett \& Aitchison, 2008; Hashimoto \& Telfer, 2006).

The three food-and-wine destinations also have natural landscapes as attraction points. In fact, the distinctiveness of the Douro Valley landscape led to the classification of world heritage by UNESCO. An interviewee showed how this recognition is valued locally with the following reference: "It was the interaction between nature and man that was worth the UNESCO classification, [...] the greatness of the territory" (Interviewee D6). The natural landscape features were also emphasised by the interviewees of the Vinho Verde region, as it is the region which integrates the only National Park of the country, as shown in Table 3. 
'Local inhabitants' was the third attribute most mentioned. This was evident in statements such as "The identity of the region lies in the local people because they made the territory" (Interviewee D6). One possible explanation for the awareness of the importance of local residents on their surrounding environment is that local people are constantly remembered of the fact that the UNESCO classification was obtained due to the human interaction with nature (landscape).

Table 3. Wine region attributes according to respondents after thematic codification

\begin{tabular}{|c|c|c|c|}
\hline Attributes & $\operatorname{TOM}(1,2,3)$ & $\mathrm{D}(4,5,6)$ & $\operatorname{VV}(7,8,9)$ \\
\hline \multirow{7}{*}{ Gastronomy } & Olive grove & & \multirow{7}{*}{$\begin{array}{l}\text { Regional sweets (traditional } \\
\text { flavours) }\end{array}$} \\
\hline & Chestnut trees $(2)^{*}$ & Wine $(2)^{*}$ & \\
\hline & Vines & Port wine & \\
\hline & Wine $(2)^{*}$ & Vines & \\
\hline & Olive oil & Lamb & \\
\hline & Almonds & & \\
\hline & Mushrooms & & \\
\hline \multirow{7}{*}{ Natural landscape } & & Landscape & \multirow{7}{*}{$\begin{array}{c}\text { River valleys } \\
\text { Seacoast } \\
\text { Mountain area } \\
\text { National Park of Peneda- } \\
\text { Gerês }\end{array}$} \\
\hline & Diversity of soils $(2)^{*}$ & Greatness of walled & \\
\hline & Natural environment & terraces & \\
\hline & Granite & Changing landscape & \\
\hline & Shale (sedimentary & (every 50 km) & \\
\hline & rock) & Remarkable & \\
\hline & & presence of vines & \\
\hline \multirow{6}{*}{ Local inhabitants } & & Friendly people & \\
\hline & & Local inhabitants & \\
\hline & & Farmers who work & \\
\hline & & the walled terraces & \\
\hline & & Humanized & \\
\hline & & territory & \\
\hline
\end{tabular}

\section{Castles}

\begin{tabular}{lcc} 
Historical heritage & $\begin{array}{c}\text { Roman olive oil mills } \\
\text { Olive oil mills arts } \\
\text { Built heritage }\end{array}$ & Romanesque Route \\
\hline Religious heritage & & Religious tourism \\
\hline
\end{tabular}

${ }^{*}$ Mentioned more than once

The role of gastronomy in regional territorial dynamics

According to the respondents there is also a growing need to apply creativity within their enogastronomic context in order to attract consumers. This relates to the work of Fox (2007), referring to the 
reinvention and 'spectacularisation' of local food products for trade, and, also, to other trends, like fostering creative enogastronomic clusters (Lee et al., 2015; Richards, 2012), the use of creative techniques in local products (Tresidder, 2015) and overall creativity in gastronomy (Pearson \& Pearson, 2017). These mixed 'creative' efforts will enable residents to build a successful regional identity.

Table 4. The role of gastronomy in regional territorial dynamics

\begin{tabular}{|c|c|}
\hline Themes & Quotations extracted from the interviews \\
\hline $\begin{array}{c}\text { Complementarity of } \\
\text { gastronomy and wine } \\
\left({ }^{* *} \text { VV9, TOM2, }\right. \\
\text { TOM1, D6, TOM3) }\end{array}$ & $\begin{array}{l}\text { *[1] Wine and gastronomy are intrinsic. } \\
\text { [2] It is necessary to associate gastronomy and wines. } \\
\text { [3] We cannot dissociate them. The wines are based on food and both } \\
\text { complement each other. } \\
\text { [4] There is no gastronomy without wines. } \\
\text { [5] The style of wine I produce is associated with the gastronomy of } \\
\text { the region. }\end{array}$ \\
\hline $\begin{array}{l}\text { Creativity in } \\
\text { enogastronomy } \\
\text { (VV8, D6, D5) }\end{array}$ & $\begin{array}{l}\text { [1] Reinventing traditional dishes [...]. } \\
\text { [2] Making wine according to the changing consumer taste is a new } \\
\text { thing. } \\
\text { [3] The dining experience is on the same level as other experiences. } \\
\text { [4] In addition to the obvious products, such as wine, jams, olive oil, } \\
\text { some handicrafts, we added apples and oranges to fairs/events [...], } \\
\text { we offered them to the festival attendees, and they ended up having } \\
\text { contact with them. }\end{array}$ \\
\hline $\begin{array}{l}\text { Gastronomy can } \\
\text { promote wine } \\
\text { (TOM1, TOM3) }\end{array}$ & $\begin{array}{l}\text { [1] Gastronomy is an excellent way to communicate wine. } \\
\text { [2] People involved in the restaurant sector present dishes and do not } \\
\text { present wines. }\end{array}$ \\
\hline $\begin{array}{l}\text { Lack of gastronomic } \\
\text { quality } \\
\text { (D5, TOM1) }\end{array}$ & $\begin{array}{l}\text { [1] Unfortunately, the region suffers from a lack of gastronomic } \\
\text { quality. If you go out for having dinner, it is hard to find restaurants } \\
\text { that are opened. } \\
\text { [2] Restaurants with local gastronomy are scarce. A region producing } \\
\text { chestnuts only has a chestnut dish during the chestnut season. }\end{array}$ \\
\hline $\begin{array}{l}\text { Micro-thematic } \\
\text { routes } \\
\text { (TOM2) }\end{array}$ & $\begin{array}{l}\text { [1] The development of an almond-themed route in Torre de } \\
\text { Moncorvo. }\end{array}$ \\
\hline
\end{tabular}

${ }^{*}$ Number of quotations; ${ }^{* *}$ Interviewees

Gastronomy was also described as a means of communicating Portuguese wine heritage. Yet, most of the restaurants are still not pairing food and local wines. Thus, combining the varietal heritage (Silva et al., 2018) with traditional and new architectural forms of landscape (e.g. 
restaurants, gourmet shops, wine cellars, wine museums) might strengthen the cultural economy (Ramos et al., 2018).

Respondents from the Douro and Trás-os-Montes regions associated the lack of gastronomic quality with the short opening hours of the restaurants, particularly during periods of high demand: "If you go out to have dinner, it is hard to find restaurants open" (Interviewees D5; TOM1). Furthermore, there is evidence that endogenous agricultural products are not always integrated in popular dishes: "A region producing chestnuts does not have a typical chestnut dish all year round, only in the chestnut season" (Interviewees D5; TOM1). But menus based on seasonal products are practically non-existent. Food providers tend to use year round menus.

In Northern Portugal it is also observed what several authors (Brunori \& Rossi, 2000; Bruwer, 2003; Corigliano, 2015) attested in other regions: micro-thematic food-and-wine routes serve not only to express the regional attributes of a place (cultural, natural and social characteristics), but also to promote local economic development.

\section{CONCLUSION}

Gastronomy and wines have become significant factors of regional distinctiveness. Portugal has followed other successful international cases by improving its wine tourism services and gastronomic products (Correia \& Ascenção, 2006). In the regions where this study was conducted, the lack of cooperation between small scale stakeholders appeared evident and putting at risk the quality of the tourism services provided. Despite the existence of some informal partnerships among medium to large-sized businesses, the food-and-wine tourism supply in Northern Portugal is fragmented. In regions where the governance mode is predominantly managed by the public sector, food, wine and tourism stakeholders demonstrated higher levels of collaboration, as well as commitment and trust (McGregor \& Robinson, 2019). This study has identified the role of the public organisations in pushing local stakeholders to establish and defend a shared vision on the endogenous products, and, thus, helping them to construct a joint territorial identity. For this reason, local initiatives, particularly those that are funded, should not only support individual stakeholders, but also foster the launch of joint activities leading to the creation of more composite tourism products. 
In this sense, different forms of collaborative activities, such as micro-thematic food routes and street food markets (harnessing local farmers' market structures), could improve community pride and lead to a unique selling proposition of the destination. Also, various sub-brands linked to the regional identity of a place could be developed (Hashimoto $\&$ Telfer, 2006). Concerning the most relevant aspects for the regions' identity, respondents agreed that the gastronomic heritage, natural landscape and local inhabitants were the main attributes of the Northern Portuguese wine regions and that they should represent in a far more conscious way a 'coherent collective identity' (Staggs \& Brenner, 2019).

The role of gastronomy in regional territorial dynamics is seen from the innovation and creative perspectives. Traditional recipes may be reformulated to attract new consumers/tourists, and to promote local food and wine pairing. As tourists are increasingly looking for personalised and memorable enogastronomic experiences, local food providers need to retro-innovate traditional recipes by adapting to current trends without losing their cultural value.

\section{Limitations and future research}

Certain limitations of the research process were identified. Given the qualitative nature of the research, time constraints and small sample size, the results cannot be generalised. Future research should be based on a broader sample of stakeholders to better understand the process of regional leadership and cooperation in building a coherent destination identity, particularly in hinterland rural areas.

This case study identified a dichotomous view of the governance structure in the collaborative dynamics of food-and-wine tourism: from a public governance intervention in a small wine sub-region to a private management perspective in larger wine regions. Further and deeper research into these two management perspectives is required.

Future research can analyse more complex international cooperative strategies. They can embody different types of network initiatives, such as the slow food movement or alternative food networks. Gaining membership of international creative food networks such as the UNESCO network of Creative Cities of Gastronomy, Portuguese foodand-wine regions may acquire new knowledge on how to exploit the unique food-and-wine attributes of a destination and, thereby reinforce 
their identity through creative strategies and, in the end, strengthen the cultural economy.

\section{ACKNOWLEDGEMENT}

This research was supported by the project NORTE-01-0145-FEDER000038 (INNOVINE \& WINE - Vineyard and Wine Innovation Platform) and by European and Structural and Investment Funds in the FEDER component, through the Operational Competitiveness and Internationalization Programme (COMPETE 2020) [Project No 006971 (UIC/SOC/04011)]; and national funds, through the FCT - Portuguese Foundation for Science and Technology under the UID/SOC/04011/2013.

\section{REFERENCES}

Alonso, A. D., \& Northcote, J. (2008). Small winegrowers' views on their relationship with local communities. Journal of Wine Research, 19(3), 143-158.

Altinay, L., \& Paraskevas, A. (2008). Planning research in hospitality and tourism. London: Routledge Taylor \& Francis Group.

Amaral, R., Saraiva, M., Rocha, S., \& Serra, J. (2016). Gastronomy and wines in the Alentejo Portuguese Region: Motivation and satisfaction of tourists from Évora. In M. Peris-Ortiz (Ed.), Wine and tourism: A strategic segment for sustainable economic development (pp. 179-192). Switzerland: Springer International Publishing.

Araújo, L. (2017). Portuguese tourism strategy 2027: Leading the tourism of the future. Worldwide Hospitality and Tourism Themes, 9(6), 646-652.

Banco de Portugal. (2014). Caracterização das empresas do setor do turismo em Portugal. Lisboa, Portugal.

Beritelli, P. (2011). Cooperation among prominent actors in a tourist destination. Annals of Tourism Research, 38(2), 607-629.

Bertella, G., Cavicchi, A., \& Bentini, T. (2018). The reciprocal aspect of the experience value: Tourists and residents celebrating weddings in the rural village of Petritoli (Italy). Anatolia, 29(1), 52-62.

Boesen, M., Sundbo, D., \& Sundbo, J. (2017). Local food and tourism: An entrepreneurial network approach. Scandinavian Journal of Hospitality and Tourism, 17(1), 76-91.

Braun, P. \& Hollick, M. (2006). Tourism skills delivery: Sharing tourism knowledge online. Education \& Training, 48(8/9), 693-703.

Brunori, G., \& Rossi, A. (2000). Synergy and coherence through collective action: Some insights from wine routes in Tuscany. Sociologia Ruralis, 40(4), 409-423.

Bruwer, J. (2003). South African wine routes: Some perspectives on the wine tourism industry's structural dimensions and wine tourism product. Tourism Management, 24, 423-435.

CCDRN (2019). Região Norte. Retrieved May 6, 2019, from http://www.ccdr-n.pt/regiaonorte/apresentacao.

Chatzopoulou, E., Gorton, M., \& Kuznesof, S. (2019). Understanding authentication processes and the role of conventions: A consideration of Greek ethnic restaurants. 
Annals of Tourism Research, 77, 128-140.

Clark, M., Riley, M., Wilkie, E., \& Wood, R. C. (2007). Researching and writing dissertations in hospitality and tourism (8th ed.). London: Thomson Learning.

Corigliano, M. A. (2015). Wine routes and territorial events as enhancers of tourism experiences. In M. Peris-Ortiz, M. de la C. D. R. Rama, \& C. Rueda-Armengot (Eds.), Wine and tourism: A strategic segment for sustainable economic development (pp. 41-56). Cham: Springer.

Correia, A., Vaughan, R., Edwards, J., \& Silva, G. (2014). The potential for cooperation between wine and tourism business in the provision of tourism experiences: The case of the Douro Valley of Portugal. Revista Portuguesa de Estudos Regionais, 36(2), $43-55$.

Correia, L., \& Ascenção, M. (2006). Wine tourism in Portugal: The Bairrada wine route. In J. Carlsen \& S. Charters (Eds.), Global wine tourism: Research, management and marketing (pp. 242-254). UK: CABI Publishing.

Creswell, J. W. (2009). Research design: Qualitative, quantitative, and mixed methods approaches (3rd ed.). USA: SAGE Publications.

CVRVV (2019). Região Demarcada dos Vinhos Verdes. Retrieved April 24, 2019, from http://www.vinhoverde.pt/pt/regiao-demarcada.

Czernek, K. (2013). Determinants of cooperation in a tourist destination. Annals of Tourism Research, 40, 83-104.

Dawson, D., Fountain, J., \& Cohen, D. A. (2011). Seasonality and the lifestyle "Conundrum": An analysis of lifestyle entrepreneurship in wine tourism regions. Asia Pacific Journal of Tourism Research, 16(5), 551-572.

Decrop, A. (1999). Triangulation in qualitative tourism research. Tourism Management, 20, 157-161.

DGADR (2019). Produtos tradicionais portugueses. Retrieved May 6, 2019, from https://radicional.dgadr.gov.pt/pt/produtos-por-regime-de-qualidade/dopdenominacao-de-origem-protegida?start $=60$.

Damayanti, M., Scott, N., \& Ruhanen, L. (2017). Coopetitive behaviours in an informal tourism economy. Annals of Tourism Research, 65, 25-35.

Dwyer, L., Gill, A., \& Seetaram, N. (2012). Handbook of research methods in tourism quantitative and qualitative approaches. Cheltenham, UK: Edward Elgar.

ENOTUR (2016). Região Vitivinícola de Trás-os-Montes. Retrieved from April 26, 2019, from http://www.enotur.pt/pt/regions/tras-os-montes.

Ellis, A., Park, E., Kim, S., \& Yeoman, I. (2018). What is food tourism? Tourism Management, 68, 250-263.

Everett, S., \& Aitchison, C. (2008). The role of food tourism in sustaining regional identity: A case study of Cornwall, South West England. Journal of Sustainable Tourism, 16(2), 150-167.

Everett, S., \& Slocum, S. L. (2013). Food and tourism: An effective partnership? A UKbased review. Journal of Sustainable Tourism, 21(6), 789-809.

Fox, D., Edwards, J., \& Wilkes, K. (2010). Employing the Grand Tour approach to aid understanding of garden visiting. In G. Richards \& W. Munsters (Eds.), Cultural tourism research methods (pp. 75-86). UK: CABI Publishing.

Fox, R. (2007). Reinventing the gastronomic identity of Croatian tourist destinations. International Journal of Hospitality Management, 26(3), 546-559.

Frochot, I. (2003). An analysis of regional positioning and its associated food images in French tourism regional brochures. Journal of Travel \& Tourism Marketing, 14(3-4), 77-96. 
Gammack, J. (2006). Wine tourism and sustainable development in regional Australia. In J. Carlsen \& S. Charters (Eds.), Global wine tourism: Research, management and marketing (pp. 59-66). UK: CABI Publishing.

Getz, D. (2000). Explore wine tourism: Management, development and destinations. New York: Cognizant Communication Corporation.

Getz, D., \& Carlsen, J. (2005). Family business in tourism: State of the art. Annals of Tourism Research, 32(1), 237-258.

Hallak, R., Brown, G., \& Lindsay, N. J. (2012). The place identity - Performance relationship among tourism entrepreneurs: A structural equation modelling analysis. Tourism Management, 33(1), 143-154.

Hashimoto, A., \& Telfer, D. J. (2006). Selling Canadian culinary tourism: Branding the global and the regional product. Tourism Geographies, 8(1), 31-55.

Haven-Tang, C., \& Jones, E. (2008). Using local food and drink to differentiate tourism destinations through a sense of place. Journal of Culinary Science \& Technology, 4(4), 69-86.

Hjalager, A. M., \& Johansen, P. H. (2013). Food tourism in protected areas: Sustainability for producers, the environment and tourism? Journal of Sustainable Tourism, 21(3), $417-433$.

IDTOUR (2016). ARVP Plano Estratégico. Aveiro, Portugal.

IVDP (2017). Rumo estratégico para o setor dos vinhos do Porto e Douro: Síntese. Vila Real, Portugal.

IVV (2015). Vinhos e aguardentes de Portugal. Lisboa.

Kim, S., \& Iwashita, C. (2016). Cooking identity and food tourism: The case of Japanese udon noodles. Tourism Recreation Research, 41(1), 89-100.

Kline, C., Shah, N., \& Rubright, H. (2014). Applying the positive theory of social entrepreneurship to understand food entrepreneurs and their operations. Tourism Planning \& Development, 11(3), 330-342.

Lai, M. Y., Khoo-lattimore, C., \& Wang, Y. (2019). Food and cuisine image in destination branding: Toward a conceptual model. Tourism and Hospitality Research, 19(2), 238251.

Lee, A. H. J., Wall, G., \& Kovacs, J. F. (2015). Creative food clusters and rural development through place branding: Culinary tourism initiatives in Stratford and Muskoka, Ontario, Canada. Journal of Rural Studies, 39, 133-144.

Lee, S., Lee, K., Chua, B., \& Han, H. (2017). Independent café entrepreneurships in Klang Valley, Malaysia - Challenges and critical factors for success: Does family matter? Journal of Destination Marketing \& Management, 6(4), 363-374.

Lin, Y., Pearson, T. E., \& Cai, L. A. (2011). Food as a form of destination identity: A tourism destination brand perspective. Tourism and Hospitality Research, 11(1), 30-48.

Marques, G. N. R. M., \& Marques, J. M. (2017). Historical and cultural wine heritage on northwest Portugal as touristic resource. Rosa dos Ventos: Turismo e Hospitalidade, 9(I), 107-119.

McGregor, A., \& Robinson, R. N. S. (2019). Wine industry and wine tourism industry collaboration: A typology and analysis. In M. Sigala \& R. Robinson (Eds.), Wine tourism destination management and marketing (pp. 381-397). Cham: Palgrave Macmillan.

Mkono, M. (2011). The othering of food in touristic eatertainment: A netnography. Tourist Studies, 11(3), 253-270.

Mykletun, R. J., \& Gyimo, S. (2010). Beyond the renaissance of the traditional Voss sheep's-head meal: Tradition, culinary art, scariness and entrepreneurship. Tourism 
Management, 31(3), 434-446.

Neuman, W. L. (2014). Social research methods: Qualitative and quantitative approaches (7th ed.). Essex, England: Pearson.

OECD (2018). Analysing megatrends to better shape the future of tourism. OECD Tourism Papers (Vol. 2). Paris: Publishing, OECD.

Ottenbacher, M. C., \& Harrington, R. J. (2013). A case study of a culinary tourism campaign in Germany: Implications for strategy making and successful implementation. Journal of Hospitality $\mathcal{E}$ Tourism Research, 37(3), 1-28.

Pearson, D., \& Pearson, T. (2017). Branding food culture: UNESCO Creative Cities of Gastronomy. Journal of Food Products Marketing, 23(3), 342-355.

PORDATA (2019). Pessoal ao serviço nas empresas: total e por sector de actividade económica. Retrieved May 7, 2019, from https://www.pordata.pt/Portugal/Pessoal.

Presenza, A., \& Chiappa, G. Del. (2013). Entrepreneurial strategies in leveraging food as a tourist resource: A cross-regional analysis in Italy. Journal of Heritage Tourism, 8(2-3), 182-192.

Quintal, V. A., Thomas, B., \& Phau, I. (2015). Incorporating the winescape into the theory of planned behaviour: Examining "new world" wineries. Tourism Management, 46, 596-609.

Rachão, S., Breda, Z., Fernandes, C., \& Joukes, V. (2019). Food tourism and regional development: A systematic literature review. European Journal of Tourism Research, 21, 33-49.

Ramires, A., Brandão, F., \& Cristina, A. (2018). Motivation-based cluster analysis of international tourists visiting a World Heritage City: The case of Porto, Portugal. Journal of Destination Marketing \& Management, 8, 49-60.

Ramos, P., Santos, V. R., \& Almeida, N. (2018). Main challenges, trends and opportunities for wine tourism in Portugal. Worldwide Hospitality and Tourism Themes, 10(6), 680687.

Richards, G. (2002). Gastronomy: an essential ingredient in tourism production and consumption? In A. M. Hjalager \& G. Richards (Eds.), Tourism and Gastronomy (pp. 3-20). London: Routledge.

Richards, G. (2012). An overview of food and tourism trends and policies. In D. Dodd (Ed.), Food and the tourism experience (pp. 13-46). Paris: OECD.

Ritchie, B. W., Burns, P., \& Palmer, C. (2005). Tourism research methods. Oxfordshire, UK: CABI Publishing.

Scorrano, P., Fait, M., Iaia, L., \& Rosato, P. (2018). The image attributes of a destination : An analysis of the wine tourists' perception a destination. EuroMed Journal of Business, 13(3), 335-350.

Serra, J., Correia, A., \& Rodrigues, P. (2015). Tourist spending dynamics in the Algarve: A cross-sectional analysis. Tourism Economics, 21(3), 475-500.

Silva, A. L. da, Fernão-Pires, M. J., \& Bianchi-de-Aguiar, F. (2018). Portuguese vines and wines: Heritage, quality symbol, tourism asset. Ciência Técnica Vitivinícola, 33(1), 3146.

Staggs, J., \& Brenner, M. (2019). Pouring new wines into old wineskins? Sub-regional identity and the case of the Basket Range Festival. In M. Sigala \& R. Robinson (Eds.), Wine tourism destination management and marketing (pp. 165-183). Cham: Palgrave Macmillan.

Sto, A., \& Vanneste, D. (2018). The role of history and identity discourses in cross-border tourism destination development: A Vogtland case study. Journal of Destination Marketing \& Management, 8, 204-213. 
Stone, M. J., Migacz, S., \& Wolf, E. (2019). Beyond the journey: the lasting impact of culinary tourism activities. Current Issues in Tourism, 22(2), 147-152.

Taylor, P., McRae-Williams, P., \& Lowe, J. (2007). The determinants of cluster activities in the Australian wine and tourism industries. Tourism Economics, 13(4), 639-656.

Telfer, D. J. (2001). Strategic alliances along the Niagara Wine Route. Tourism Management, 22, 21-30.

Thomas, R., Shaw, G., \& Page, S. J. (2011). Understanding small firms in tourism: A perspective on research trends and challenges. Tourism Management, 32(5), 963-976.

Ting, H., Fam, K., Hwa, J., Richard, J. E., \& Xing, N. (2019). Ethnic food consumption intention at the touring destination: The national and regional perspectives using multi-group analysis. Tourism Management, 71, 518-529.

Tresidder, R. (2015). Eating ants: Understanding the terroir restaurant as a form of destination tourism. Journal of Tourism and Cultural Change, 13(4), 344-360.

Turismo de Portugal. (2014). O enoturismo em Portugal: Caraterização da oferta e da procura. Lisboa, Portugal.

Turismo de Portugal. (2016). Estratégia Turismo 2027. Lisboa, Portugal.

Veal, A. J. (2006). Research methods for leisure and tourism. A practical guide. Pearson Education Limited (3rd ed.). Essex, England: Prentice Hall.

Verma, V., \& Chandra, B. (2018). Sustainability and customers' hotel choice behaviour: a choice-based conjoint analysis approach. Environment, Development and Sustainability, 20(3), 1347-1363.

Wang, Y., \& Xiang, Z. (2007). Toward a theoretical framework of collaborative destination marketing. Journal of Travel Research, 46, 75-85.

Wines of Portugal. (2016). Regiões Vitivinícolas. Portugal. Retrieved May 4, 2019, from http://www.winesofportugal.info/pagina.php? $\operatorname{codNode}=18012$

Yeap, J., Ong, K., Yapp, E., \& Ooi, S. (2019). Hungry for more: Understanding young domestic travellers' return for Penang street food. British Food Journal, ahead-of-print (ahead-of-print). https://doi.org/10.1108/BFJ-09-2018-0632

Zhang, X., Song, H., \& Huang, G. Q. (2009). Tourism supply chain management: A new research agenda. Tourism Management, 30(3), 345-358. 